\title{
Effect of broad bed furrow method for rainfed soybean cultivation at Balodabazar district of Chhattisgarh
}

\author{
P.D. VERMA, PARMANAND AND S.K. TAMRAKAR
}

Received : 21.03.2017; Revised : 15.07.2017; Accepted : 29.07.2017

See end of the Paper for authors' affiliation

Correspondence to :

\section{PARMANAND}

Krishi Vigyan Kendra, Bhatapara, RAIPUR (C.G.) INDIA

Email : erparmanandsahu@ gmail.com
-ABSTRACT : A field study was carried out during Kharif 2014-15, 2015-16, and 2016-17 on thirty seven farmers field of Mohbhatta village of Simga block of the district Balodabazar-Bhatapara of Chhattisgarh state with size of trial is one acre each farmers to determine the impact of sowing techniques on yield of soybean under farmers' conditions. Soybean is more water stress crop and at the time of germination sudden rainfall affects the crop. For this purpose, broad bed planting technology was introduced in the study area to compare it with the conventional sowing of soybean by flat bed methods. Six-row broad bed furrow machine was used to plant soybean having top bed width of $2.35 \mathrm{~cm}$. Result showed that growth character (plant height, number of branches per plant and number of root nodules per plant) and yield contributing character viz., number of pods per plant, seed yield weight per plant, seed index, seed yield,straw yield and harvest index (\%) were found higher in broad bed furrow compared to the normal flat bed sowing which subsequently resulted in yield enhancement to the extent of $28.38 \%$ for soyabean crop. The average yield in broad bed furrow method recorded $15.20 \mathrm{q} \mathrm{ha}^{-1}$. The B:C ratio was observed 2.05 due to drainage of excessive rain water from the fields and stronger plant anchorage on the beds. Similarly, 40 to $50 \%$ saving in irrigation water was recorded with broad bed furrow method of soybean in comparison with flood irrigation of controlled plots. Results indicated that broad bed furrow technology has a lot of potential to increase water productivity of soybean.

- KEY WORDS : Broad bed furrow, Flat bed, Soybean

- HOW TO CITE THIS PAPER : Verma, P.D., Parmanand and Tamrakar, S.K. (2017). Effect of broad bed furrow method for rainfed soybean cultivation at Balodabazar district of Chhattisgarh. Internat. J. Agric. Engg., 10(2) : 297-301, DOI: 10.15740/HAS/IJAE/10.2/297-301. 